not been normal. Secretary Eden remarked in the House of Commons on April 13 that "the natural thing to have done when the struggle had reached the large dimensions of the present war in Spain was to have recognized its belligerent character, and for those whose maritime interests were involved like ours to grant belligerent rights." It is believed that unless the circumstances of the particular case are quite abnormal, or where recognition would affect prejudicially the recognizing state's own rights or would operate to the detriment of the general interests of the community of states, the withholding of recognition cannot be justified, assuming of course that the struggle has acquired the proportions of a war in the material sense. It is hardly necessary to add that the decision of the foreign government should not be influenced by its own sympathies or prejudices.

James W. Garner

\title{
THE LIQUIDATION OF PERPETOAL LEASES IN JAPAN
}

Current discussion of "peaceful change" serves to emphasize the importance of the notes exchanged between the Japanese Government and eight other governments, during the months of March and April, 1937, "with a view to liquidating once and for all in a spirit of friendship and conciliation the system of perpetual leases" in Japan.

The perpetual leases had their origin at a time when aliens were not permitted to own lands freely in Japan, and when a number of foreign settlements existed there. Provisions for the residence of certain aliens were embodied in a series of Japanese treaties of 1858-1869. The treaty with the United States of July 29,1858 , was the first of the series, but the most explicit of such provisions were those in the treaty with Austria-Hungary of October 18, 1869 (Article 3). ${ }^{1}$ Settlements were laid out to meet the needs of aliens in fulfilment of these treaty provisions, and within these settlements land was "held under governmental leases in perpetuity ... subject to a fixed rate of rent

1 Article 3 of this treaty provides in part: "The ports and towns of Yokohama (in the district of Kanagawa), Hiogo, Osaka, Nagasaki, Niigata, Ebisuminato on the island of Sado, Hakodate and the City of Tokei (Yedo) shall, from the day on which this Treaty comes into operation, be opened to the citizens of the Austro-Hungarian Monarchy, and to their trade.

"In the above ports and towns Austro-Hungarian citizens may permanently reside; they shall have the right, therein to lease land, to purchase houses, and to erect dwellings and warehouses.

"The place, where Austro-Hungarian citizens shall reside, and where they shall erect their buildings, shall be determined on by the Imperial and Royal Consular Officers in conjunction with the competent local Authorities; the harbour regulations shall be arranged in a similar manner.

"If the Imperial and Royal Consular Officers and the Japanese Authorities can not agree, the matter shall be submitted to the Diplomatic Agent and the Japanese Government." Treaties and Conventions between the Empire of Japan and other Powers (Tokio, 1884), p. 4. This provision has been said to "contain the sum of all privileges and immunities on the subject [of the leaseholds] granted by Japan under the Treaties of 1858-1869." Case of Japan in the Japanese House Tax Case, p. 13. 
per tsubo"; this land was (or became) "the property of the State and in consequence exempt from taxation of all kinds." 2 The principal settlements were in Yokohama, Nagasaki, Hiogo, Osaka and Tokio. In presenting its case to a tribunal of the Permanent Court of Arbitration in 1904, the Japanese Government stated that 511,150.89 tsubo of land were held under perpetual leases in these settlements. ${ }^{3}$ Some lands in Hakodate were also held under perpetual lease, though no settlement was laid out there. While the holders of the leaseholds were of various nationalities, much of the lands, in recent times at least, were held by British subjects, the interests of American nationals being second in importance. ${ }^{4}$

Numerous taxation questions arose in connection with the perpetual leaseholds, but so long as extraterritorial jurisdiction existed in Japan it was not possible for the Japanese Government to effect the collection of taxes the levying of which it thought to be permitted. This situation was changed in some degree by the disappearance of extraterritoriality in 1899. The series of treaties which provided for the abolition of extraterritoriality contained provisions for the continuance of the leaseholds. The treaty concluded between Japan and Great Britain on July 16, 1894, the first treaty of that series, contained the following (Article 18): ${ }^{\circ}$

Her Britannic Majesty's Government, so far as they are concerned, give their consent to the following arrangement:

The several foreign Settlements in Japan shall be incorporated with the respective Japanese Communes, and shall thenceforth form part of the general municipal system of Japan.

The competent Japanese authorities shall thereupon assume all municipal obligations and duties in respect thereof, and the common funds and property, if any, belonging to such Settlements, shall at the same time be transferred to the said Japanese authorities.

When such incorporation takes place, existing leases in perpetuity under which property is now held in the said Settlements shall be confirmed, and no conditions whatsoever other than those contained in such existing leases shall be imposed in respect of such property. It is, however, understood that the Consular authorities mentioned in the same are in all cases to be replaced by the Japanese authorities.

All lands which may previously have been granted by the Japanese Government free of rent for the public purposes of the said Settlements shall, subject to the right of eminent domain, be permanently reserved

2 Case of Japan in the Japanese House Tax Case, pp. 15-16. The tsubo is the equivalent of 3.305785 square meters, $i d .$, p. 17 ; an acre is about 1225 tsubo.

3Id., p. 67. See, also, Reischauer, "Alien Land Tenure in Japan," in Transactions of the Asiatic Society of Japan, 2d series, Vol. XIII.

t On March 25, 1937, a Japanese "Foreign Office Spokesman" was reported to have said that "out of a total of 146,000 tsubo of land (about 119 acres) held under perpetual lease, 64,000 tsubo (about 52 acres) represents the land held by British and 32,000 tsubo (about 26 acres) by American nationals." 6 Contemporary Japan (Jure, 1937), p. 170. See also 16 Department of State Press Releases (March 6, 1937), p. 134; 6 Far Eastern Survey (May 12, 1937), p. 107.

s6 British and Foreign State Papers, p. 46. See also Arts. 1 and 3 of the same treaty. 
free of all taxes and charges for the public purposes for which they were originally set apart.

Substantially similar provisions for the continuance of the leaseholds were incorporated in treaties concluded by Japan with the United States of America, November 22, 1894 (Article 17) ; with Russia, June 8, 1895 (Article 17) ; with Germany, April 4, 1896 (Article 19) ; with Belgium, June 22, 1896 (Article 17) ; with France, August 4, 1896 (Article 21) ; with Switzerland, November 10, 1896 (Article 12); with Spain, January 2, 1897 (Article 17) ; with Portugal, January 26, 1897 (Article 17) ; and with Austria-Hungary, December 5, 1897 (Article 20). Most-favored-nation clauses in certain treaties, notably in the treaties concluded by Japan with Denmark, October 19, 1895, and with The Netherlands, September $8,1896,{ }^{6}$ extended the benefit of these provisions to other states.

After the revised treaties came into force, the Japanese Government took the position that the exemption from taxation did not extend to improvements on the lands held under the leases. This view was controverted by the British, French and German Governments, and on August 28, 1902, these governments agreed with the Japanese Government to submit the question to an arbitral tribunal composed of three members of the Permanent Court of Arbitration. In its judgment in the so-called Japanese House Tax Case, on May 22, 1905, that tribunal decided, by a majority of votes, that the buildings as well as the lands were exempt from taxation.

Though the result of the arbitral judgment was accepted by the Japanese Government, questions of taxation continued to arise and to give difficulty, and it is easy to understand the desire of the Japanese Government to find an escape from the system altogether. When the British-Japanese Treaty of Commerce and Navigation of April 3, 1911, was being negotiated, it was agreed that "the contention of either Government regarding the position of the holders of leases in perpetuity in the former foreign settlements, which it was agreed between the two Governments should form the subject of a separate negotiation, was not in any way prejudiced by the omission of reference to that question in the Treaty." 8 In succeeding years, attempts were made to settle the question, but active negotiations were discontinued in 1914. Meanwhile, in 1925, aliens were given extensive privileges of owning land in Japan, subject to certain restrictions. ${ }^{9}$

Recently the British Government took the lead in negotiating a settlement of the problem, and its lead was followed by other governments. On March

- These treaties are collected in Treaties and Conventions between the Empire of Japan and Other Powers (Tokio, 1899).

7 Scott, Hague Court Reports, p. 77.

- Recueil des Traites et Conventions entre le Japon et les Puissances Etrangeres (1925), I, p. 745 .

- Reischauer, op. cit., pp. 123-130; Yamada, in McKenzie's Legal Status of Aliens in Pacific Countries (1937), p. 211. 
25, 1937, both the American and British Governments exchanged notes with the Japanese Government for the abolition of the "system of perpetual leases"; ${ }^{10}$ the "understanding" embodied in these notes is to the effect:

(1) That the said system of perpetual leases shall come to an end on the first day of the fourth month of the seventeenth year of Showa, corresponding to the 1st day of April, 1942, when the leaseholds shall without compensation be converted into the rights of ownership in accordance with the provisions of Japanese laws and ordinances. Such conversion shall be effected free of registration taxes in respect of lands under perpetual leases and buildings thereon.

(2) That until the thirty-first day of the third month of the seventeenth year of Showa, corresponding to the 31st day of March, 1942, the present position as regards tax exemptions shall be maintained, ${ }^{11}$ and no further claims shall be made by the Japanese authorities for arrears of such disputed taxes as may still be uncollected.

Similar notes were exchanged by the Japanese Government with the Governments of France and Switzerland on April 15, 1937, and with the Governments of Denmark, Italy, Portugal, and The Netherlands on April 30,1937. ${ }^{12}$

In announcing the understanding with Japan, the Department of State of the United States said that "a coöperative attitude has thus far been manifested by American leaseholders, and it is confidently expected that, by accepting the terms of settlement, they will contribute to the promotion of friendly international relations." 13 This statement does not imply a legal necessary for affirmative action of acceptance by the leaseholders.

\section{Manley O. Hudson}

\section{THE DEFENSE OF OPPRESSED PEOPLES}

One hears currently much agitation in favor of action by the Government of the United States to assist peoples which are oppressed by foreign aggressors, by national governments or by domestic conflicts. Thus it is urged by some that the United States should do something to aid the Loyalists in Spain, chiefly on the ground that their enemies are being aided by Germany and Italy and that the Insurgents are waging cruel warfare. It is urged that the United States should do something to aid the Chinese against Japanese aggression. It was urged that the United States should do something to help the

${ }^{10}$ U. S. Executive Agreement Series, No. 104; British Treaty Series, No. 29 (1937).

u Elaborating this expression, a second exchange of notes between the United States and Japan, also of March 25, 1937, provided that "until March 31, 1942, no taxes at present in force shall be collected other than those heretofore collected from the leaseholders, nor shall any taxes which may be introduced in the future be collected from the leaseholders if such taxes are directly connected with the perpetual leaseholds." It was also stipulated that "in the event of an American leasehold being transferred it . . . shall continue to be subject to the terms of the understanding" reached. U. S. Executive Agreement Series, No. 104.

1236 (Japanese) Journal of International Law and Diplomacy, No. 6 (July, 1937).

${ }^{18} 16$ Department of State Press Releases (March 6, 1937), p. 134. 